\title{
Hubungan Karakteristik individu dan Perilaku Caring Perawat Dengan Kepuasan pasien di Ruang Rawat Inap RSUD Abdul Manap Jambi Tahun 2019
}

\author{
Ernawati $^{1 *}$, Bettywati E Tumanggor ${ }^{2}$ \\ ${ }^{1,2}$ Institusi Jurusan Keperawatan Poltekkes Kemenkes Jambi \\ "Correspondence email: ernawatisyaraif@yahoo.com
}

\begin{abstract}
Abstrak. Pelayanan keperawatan mempunyai peranan besar dalam meningkatkan dan menentukan keberhasilan mutu pelayanan kesehatan. caring adalah komponen penting dalam keperawatan dan merupakan inti dari praktek keperawatan karena mengandung nilai-nilai humanistik, menghormati kebebasan manusia terhadap suatu pilihan, menekankan pada peningkatan kemampuan dan kemandirian, peningkatan pengetahuan dan menghargai setiap manusia. Perawat yang mempunyai nilai dan jiwa caring akan mempunyai perilaku kerja yang sesuai dengan prinsip etik dikarenakan kepedulian perawat yang memandang klien sebagai makhluk humanistik sehingga termotivasi untuk memberikan pelayanan keperawatan yang bermutu tinggi. Penelitian ini merupakan penelitian kuantitatif dengan desain deskripsi korelasi dengan pendekatan cross sectional untuk melihat hubungan karakteristik individu dan perilaku caring perawat sebagai variabel independen dan kepuasan pasien sebagai variable dependent. Tujuannya adalah untuk mengetahui hubungan karakteristik individu dan perilaku caring perawat dengan kepuasan pasien rawat inap RSUD Abdul Manap Jambi. Sampel pasien yang dirawat diruang rawat inap kelas 1 dan VIP, cara pengambilan sampel dengan accidental sampling. Pengolahan data dengan analisis chi-square. Berdasarkan hasil penelitian gambaran karakteristik individu sebagian besar: responden jenis kelamin laki-laki (56,7\%), pendidikan rendah (83,3\%), umur berusia diatas 46 tahun $(56,7 \%)$, dan bekerja $(61,7 \%)$. Perilaku caring perawat sebagian besar berperilaku baik $(73,3 \%)$ dan $70 \%$ pasien puas terhadap pelayanan diruang rawat inap RSUD Abdul Manap Kota Jambi. Hasil analisis bivariate Tidak ada hubungan karakteristik individu dengan kepuasan pasien rawat inap dan ada hubungan perilaku caring perawat dengan kepuasan pasien rawat inap di RSUD Abdul Manap Kota Jambi ( $p$ value 0,018). Hasil penelitian diharapkan dapat meningkatkan mutu pelayanan keperawatan terutama dalam memberikan asuhan keperawatan dengan memperhatikan aspek caring untuk meningkatkan kepuasan pasien rawat inap.Bagi perawat diruang rawat inap konsisten dan lebih meningkatkan aplikasi caring dalam memberikan asuhan keperawatan pada pasien terutama dalam pemenuhan kebutuhan dasar dan pendidikan kesehatan diruang rawat inap.
\end{abstract}

Kata kunci: Karakteristik individu; perilaku caring; kepuasan pasien

\begin{abstract}
Nursing services have a big role to play in improving and determining the quality of health care. caring is an important component in nursing and is at the core of nursing practice because it contains humanistic values, respects human freedom of choice, emphasizes on improving ability and self-reliance, increasing knowledge and respecting every human being. Nurses who have value and caring spirit will have work behaviors that are in accordance with the principles of ethics due to the care of nurses who view clients as humanistic beings so motivated to provide high quality nursing services. This study is a quantitative study with a design description of correlation with a cross sectional approach to view the relationship of individual characteristics and caring behavior of nurses as independent variables and patient satisfaction as variable dependent. The goal is to know the relationship of individual characteristics and behavior of caring nurses with the satisfaction of inpatients of Abdul Manap Jambi Hospital. Samples of patients treated in the first and VIP inpatient rooms, how to take samples by accidental sampling. Data processing with chi-square analysis. Based on the results of the study the characteristics of individuals are mostly: male gender respondents (56.7\%), low education (83.3\%), age over 46 years (56.7\%), and work (61.7\%). Caring behavior of nurses is mostly well behaved (73.3\%) and 70\% of patients are satisfied with the services provided in the inpatient room of RsUD Abdul Manap Kota Jambi. The results of bivariate analysis there is no relationship of individual characteristics with the satisfaction of inpatients and there is a relationship of caring behavior of nurses with the satisfaction of inpatients in Abdul Manap Hospital Jambi City ( $p$ value 0.018). The results of the study are expected to improve the quality of nursing services, especially in providing nursing care by taking into account caring aspects to improve the satisfaction of inpatients. For nurses in the inpatient room consistently and further improve caring application in providing nursing care to patients especially in the fulfillment of basic needs and health education in the inpatient room.
\end{abstract}

Keywords: Individual characteristics; caring behavior; patient satisfaction

\section{PENDAHULUAN}

Pelayanan keperawatan mempunyai peranan besar dalam meningkatkan dan menentukan keberhasilan mutu pelayanan kesehatan. Hasil penelitian Huber (1996) dalam Wiyana (2008) menyatakan bahwa 90\% pelayanan yang diberikan di rumah sakit adalah pelayanan keperawatan. Dengan demikian baik buruknya pelayanan kesehatan di suatu rumah sakit sangat ditentukan oleh kualitas pelayanan keperawatan itu sendiri (Wiyana, 2008). Caring secara umum dapat diartikan sebagai suatu kemampuan untuk berdedikasi bagi orang lain, pengawasan dengan 
waspada, perasaan empati pada orang lain dan perasaan cinta atau menyayangi.

Nursalam (2002) menyatakan bahwa caring adalah komponen penting dalam keperawatan dan merupakan inti dari praktek keperawatan karena mengandung nilai-nilai humanistik, menghormati kebebasan manusia terhadap suatu pilihan, menekankan pada peningkatan kemampuan dan kemandirian, peningkatan pengetahuan dan menghargai setiap manusia. Perawat yang mempunyai nilai dan jiwa caring akan mempunyai perilaku kerja yang sesuai dengan prinsip etik dikarenakan kepedulian perawat yang memandang klien sebagai makhluk humanistik sehingga termotivasi untuk memberikan pelayanan keperawatan yang bermutu tinggi (Nursalam, 2002).

Pelayanan kesehatan yang bermutu merupakan faktor yang penting dalam mencapai kepuasaan pasien . Kepuasan pasien adalah suatu tingkat perasaan pasien yang timbul sebagai akibat dari kinerja layanan kesehatan yang diperoleh setelah pasien membandingkan dengan apa yang diharapkan. Kepuasan pasien tergantung dengan kualitas layanan yang diberikan. Menurut Carr dan Hill 1992 dalam Baros (2011) menyatakan bahwa derajat kepuasaan pelanggan dipengaruhi oleh kedudukan sosial, tingkat ekonomi, budaya, pendidikan , umur, dan jenis kelamin.

As'ad (2011) mengemukakan bahwa kepuasan
adalah tingkat perasaan seseorang setelah membandingkan antara pencapaian hasil (kenyataan) dengan harapan (yang seharusnya) Kepuasan sebagai indikator mutu pelayanan kesehatan dan keperawatan berhubungan dengan proses pelayanan dan hubungan antar pribadi antara pemberi pelayanan dengan penerima pelayanan (interpersonal relationships), yaitu saling percaya, kepedulian, perhatian, kepekaan akan kebutuhan-kebutuhan atau masalah klien, serta sistem pengaturan dirumah sakit (lingkungan, fasilitas, alur klien, waktu tunggu, dan sebagainya) (Spiegel\&Backhaut,2008).Hasil penelitian yang terkait dengan perilaku caring dan kepuasan pasien yang dilakukan Ikafah 2017 didapatkan sebagian besar pasien menganggap perilaku caring perawat baik $(82,5 \%)$, lebih dari setengah pasien puas terhadap pelayanan keperawatan $(75,0 \%)$, ada hubungan perilaku caring perawat dengan kepuasan pasien di Ruang Rawat Inap Private Care Centre RSUP Dr Wahidin Sudirohusodo Makassar $(\mathrm{p}=0,006)$ Hal ini berlandaskan pendapat Wijono (1999) yang menyebutkan perilaku caring perawat sangat penting dalam memenuhi kepuasan pasien. Selain itu, beberapa penelitian terdahulu telah membuktikan adanya hubungan antara perilaku caring perawat dengan kepuasan pasien.

Rumah Sakit Umum Abdul Manap Kota Jambi merupakan rumah sakit pemerintah daerah dengan fasilitas rujukan tingkat Pertama, dengan jumlah pasien rawat inap tahun 2018 sebanyak 6679 orang, BOR tahun $2018(36,70 \%)$. Studi pendahuluan peneliti lakukan di ruang perawatan rawat inap RSUD Abdul Manap Kota Jambi terhadap 5 orang pasien. Hasil studi pendahuluan ini didapat 2 orang pasien mengatakan bahwa perawat kadang masih kurang sabar mendengarkan keluhan pasien, jika dibutuhkan perawat kurang cepat tanggap. Selanjut 3 pasien dengan jenis kelamin lakilaki berpendapat bahwa perawat sering memberikan dukungan dan motivasi untuk sembuh. Sedangkan keluarga pasien sebanyak 5 orang menilai bahwa perawat cepat tanggap terhadap keluhan pasien, tapi masih ada juga perawat kurang sabar dan belum mengutamakan kepentingan pasien dalam memberikan asuhan keperawatan. Tingkat kepuasan pasien terhadap pelayanan keperwatan belum sesuai dengan yang diharapkan oleh pasien dan keluarga. Dari wawancara peneliti dengan kepala bidang keperawatan selama ini perilaku caring perawat masih belum optimal dan perlu penyegaran tentang pemahaman dan implementasi perilaku caring dalam memberikan asuhan keperawatan serta penelitian yang terkait dengan perilaku caring dan kepuasan pasien belum pernah dilakukan.

\section{METODE}

Penelitian ini merupakan penelitian kuantitatif dengan desain Cross Sectional. Tujuan dari penelitian ini adalah untuk mengetahui hubungan karakteristik individu (umur, jenis kelamin, pendidikan, pekerjaan) dan perilaku caring perawat dengan kepuasan pasien.

Penelitian ini dilakukan di ruang rawat inap Rumah Sakit Umum Daerah Abdul Manap Kota Jambi. Waktu penelitian 14-26 Oktober 2019.

Populasi dalam penelitian ini adalah seluruh pasien rawat inap tahun 2018 yang berjumlah 3918 pasien,sampel dalam penelitian ini yaitu sejumlah pasien yang mewakili populasi yang dirawat pada ruang perawatan Rumah Sakit Umum Daerah Abdul Manap Kota Jambi tahun 2019 diruang Bedah, interne, jantung, Paru, THT/ mata dan ruang VIP. Jumlah sampel 60 orang .Pengambilan Sampel secara Proposional. Pengambilan Sampel dilakukan secara accidental sampling dengan mengambil sampel yang mewakili masing-masing ruang rawat inap sesuai proporsi pada saat dilakukan penelitian. Instrumen yang digunakan dalam penelitian ini adalah kuesioner yang diisi oleh seluruh responden.

Analisis Data secara analisis Univariat bertujuan untuk melihat gambaran perilaku caring perawat dan kepuasan pasien di ruang perawatan Rumah Sakit Umum Daerah Abdul Manap tahun 2019, Analisis Bivariat Bertujuan untuk mengetahui hubungan antara variable independent dan variabel dependent Sugiyono ,2012. Uji statistik yang dilakukan dalam penelitian ini terdiri dari dua uji yaitu Pertama chi square untuk variabel independent dan variabel dependent yang kategorik. Dalam uji ini menggunakan tingkat kemaknaan (nilai alpa) sebesar $(0,05)$. Variabel yang 
Ernawati dan Bettywati E Tumanggor, Hubungan Karakteristik individu dan Perilaku Caring Perawat Dengan Kepuasan pasien di Ruang Rawat Inap RSUD Abdul Manap Jambi Tahun 2019

memiliki P- value kurang dari alfa, maka disimpulkan adanya hubungan diantara variabel.
HASIL DAN PEMBAHASAN

Karakteristik Responden

Tabel 1. Distribusi frekuensi Karakteristik Responden

\begin{tabular}{cllcc}
\hline No & \multicolumn{1}{c}{ Variabel } & \multicolumn{1}{c}{ Kategori } & $\mathrm{n}=60$ & Prosentase \\
\hline 1. & Umur & Remaja akhir & 8 & 13,3 \\
& & Dewasa & 18 & 30,0 \\
& & Lansia & 34 & 56.7 \\
\hline 2. & Jenis Kelamin & Laki-laki & 34 & 56,7 \\
& & Perempuan & 26 & 43,3 \\
\hline 3. & Status pekerjaan & Bekerja & 37 & 61,7 \\
& & Tidak bekerja & 23 & 38,3 \\
\hline 4. & Tingkat Pendidikan & Pendk dasar & 27 & 45,0 \\
& & Pend menengah & 24 & 40,0 \\
& & Pendidk tinggi & 9 & 15,0 \\
\hline
\end{tabular}

Hasil penelitian tentang karakteristik responden didapatkan bahwa, distribusi responden menurut jenis kelamin lebih banyak adalah responden dengan jenis kelamin laki-laki 34 (56,7\%). Menurut umur yang terbanyak adalah responden yang berusia > 46 tahun (lansia) yaitu $34(56,7 \%)$. Adapun menurut Tingkat pendidikan yang terbesar adalah pendidikan dasar yaitu 50 orang $(45,0 \%)$.Sedangkan proporsi terbesar responden menurut pekerjaan adalah sebagian besar bekerja yaitu 37 orang $(61,7 \%)$. Berdasarkan hasil penelitian karakteristik responden tidak berhubungan dengan kepuasan pasien rawat inap di RSUD Abdul Manap Kota Jambi.

Meenurut Gary Lee Cloud (2003), bahwa laki-laki memiliki kepuasan lebih tinggi dari perempuan, penelitian ini menunjukkan hubungan yang negatif yaitu pasien perempuan lebih banyak puas $(73,1 \%)$ dibandingkan dengan pasien laki -laki., usia yang muda memiliki tingkat kepuasaan yang relatif rendah dibandingkan dengan usia tua karena usia lebih muda lebih produktif dan memiliki harapan besar hal ini sejalan dengan hasil penelitian bahwa umur $\geq 46$ tahun cendrung lebih puas dibanding usia yang lebih muda.

Berdasarkan hasil penelitian Karakteristik pendidikan menunjukan kecndrungan hubungan yang positif artinya semakin rendah tingkat pendidikan akan merasa lebih cepat puas terhadap layanan diberikan sedangkan yang berpendidikan tinggi lebih kritis dalam menerima layanan yang tidak sesuai dengan kenyataan.

Dan untuk karakteristik pekerjaan hasil penelitian menunjukan tidak ada hubungan dengan tingkat kepuasaan, hal ini tidak sesuai dengan pendapat Parasuraman (1999) mengatakan bahwa pekerjaan seseorang mempengaruhi penghasilan, sehingga responden yang bekerja lebih cendrung akan membuat lebih banyak tuntutan sehingga akan mempengaruhi tingkat kepuasan.
Gambaran Perilaku Caring Perawat dan Tingkat Kepuasan Pasien di Ruang rawat Inap RSUD Abdul Manap Kota Jambi

Gambaran perilaku caring perawat yang dipersepsikan pasien dalam memberikan asuhan keperawatan dan tingkat kepuasan pasien seperti diagram berikut ini:

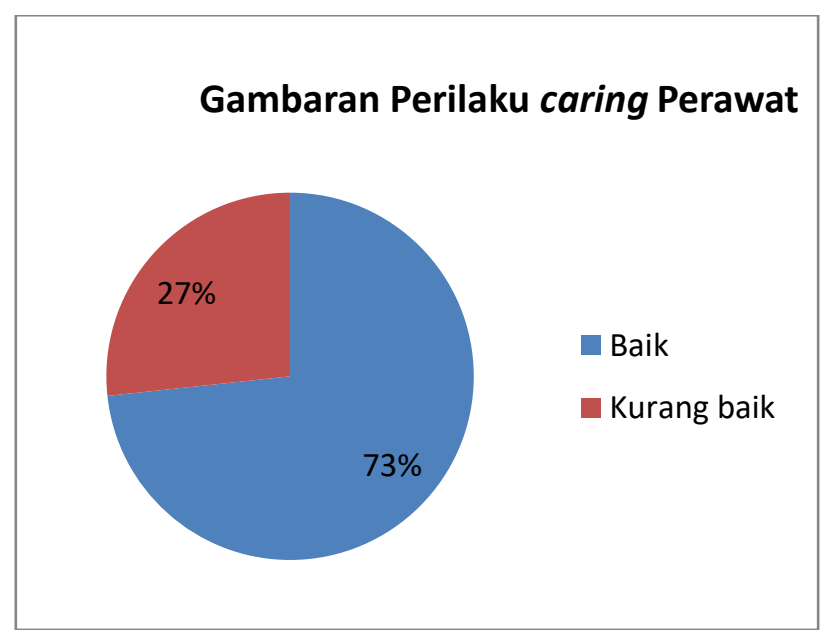

Gambar 1. Perilaku caring perawat

\section{Gambaran Tingkat kepuasan Pasien}

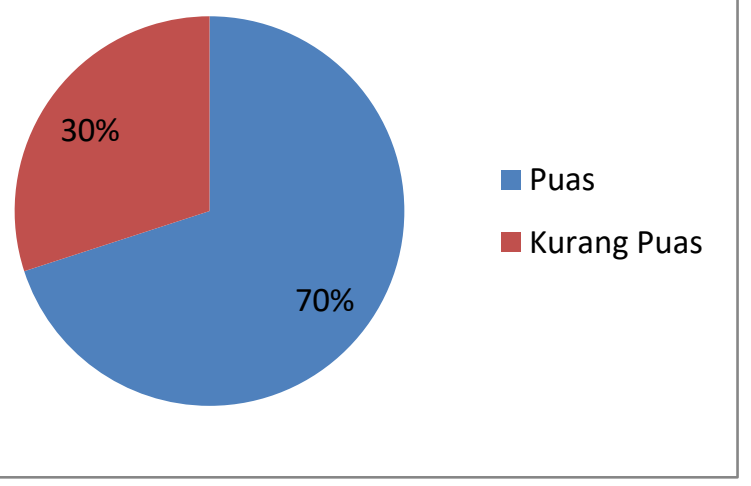

Gambar 2. Tingkat kepuasan pasien 
Berdasarkan diagram diatas diketahui bahwa distribusi responden berdasarkan perilaku caring perawat, sebagian besar adalah responden mempersepsikan perilaku caring perawat baik yaitu 44 orang $(73,3 \%)$, sedangkan perilaku caring kurang baik yaitu 16 orang $(26,7 \%)$. Hasil penelitian berdasarkan tingkat kepuasan, sebagian besar adalah responden puas terhadap pelayanan yang diberikan perawat yaitu 42 orang (70\%), sedangkan responden kurang puas yaitu 18 orang $(30 \%)$.

Berdasarkan hasil penelitian menunjukan perilaku caring perawat sebagian besar $44(73.3 \%)$ pasien menilai perilaku caring perawat baik. Caring dipersepsikan oleh klien sebagai ungkapan cinta dan ikatan, otoritas dan keberadaan, selalu bersama, empati, dapat memotivasi perawat untuk dapat lebih care pada klien dan mampu melakukan tindakan sesuai kebutuhan klien. Semakin baik perilaku caring perawat dalam memberikan pelayanan asuhan keperawatan, klien atau keluarga semakin senang dalam menerima pelayanan, berarti hubungan terapeutik perawat-klien semakin terbina.Hasil penelitian ini sejalan dengan penelitian ikafah 2017 perilaku caring perawat baik $82,5 \%$. Namun hasil penelitian berdasarkan 10 faktor caratif caring masih ada responden mempersepsikan perawat tidak pernah ( $1,6 \%)$ bersikap sabar mendengarkan keluahan pasien,, memenuhi kebutuhan dasar baik fisik,social dan spiritual dan memelihara lingkungan yang menghormati nilai budaya, adat istiadat dan agama pasien. Serta responden masih ada menjawab kadang -kadang untuk pertanyaan memahami pasien secara terbuka dan jujur $(6,6 \%)$, memberikan pendidikan kesehatan ( $10 \%)$, Menciptkan lingkungan yang kondusif dan nyaman serta memenuhi kebutuhan dasar $(3,3 \%)$.

Perilaku caring adalah suatu tindakan yang didasari oleh kepedulian, kasih sayang, keterampilan, empati, tanggung jawab, sensitif, dan dukungan. Perilaku ini berfungsi untuk memperbaiki atau meningkatkan kondisi dan cara hidup manusia yang menekankan pada aktivitas yang sehat dan memampukan individu serta kelompok berdasarkan budaya. Perawatan yang berdasarkan nilai-nilai humanistik dan altruistik dapat dikembangkan melalui penilaian terhadap pandangan diri seseorang, kepercayaan, interaksi dengan berbagai kebudayaan dari pengalaman pribadi. Hal ini dianggap penting untuk pendewasaan diri perawat yang kemudian akan meningkatkan sikap dan perilaku caring dalam memberikan asuhan keperawatan terutama untuk tindakan dalam pemenuhan kebutuhan pasien, memberikan pendidikan kesehatan serta menciptakan lingkungan yang aman dan nyaman bagi pasien

Selanjutnya untuk mengetahui perilaku caring perawat untuk setiap item pertanyaan dapat dilihat seperti diagram batang berikut ini:

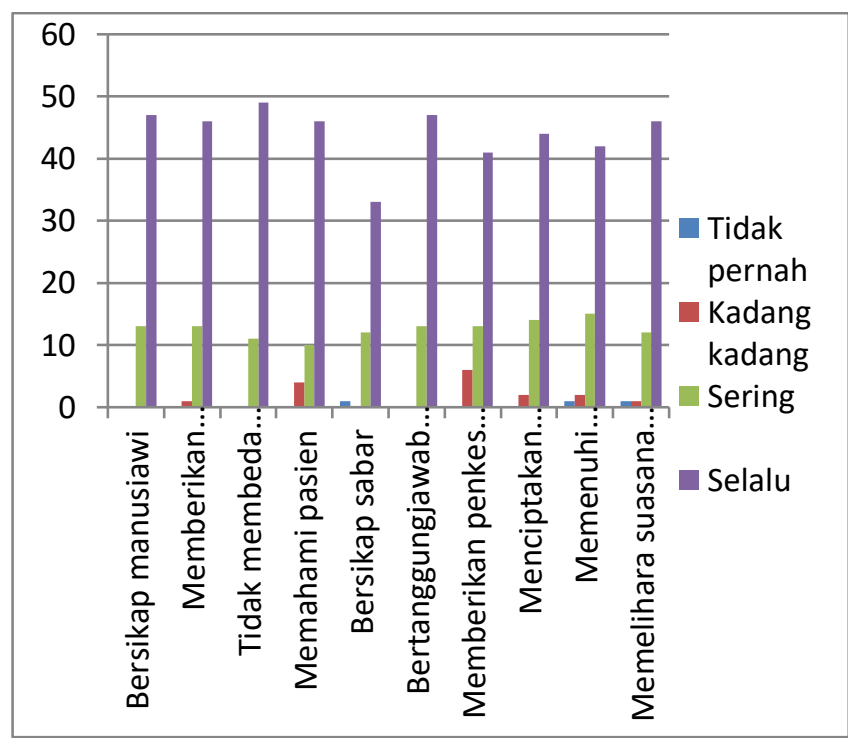

Gambar 3. Distribusi Responden Berdasarkan Perilaku Caring Perawat di RSUD Abdul Manap Kota Jambi Tahun 2019

Hasil penelitian menunjukan bahwa sebagian besar responden sudah sering dan selalu menerapkan perilaku caring dalam memberikan asuhan keperawatan, namun masih ada responden mempersepsikan perawat tidak pernah $(1,6 \%)$ bersikap sabar mendengarkan keluahan pasien,, memenuhi kebutuhan dasar baik fisik,social dan spiritual dan memelihara lingkungan yang menghormati nilai budaya, adat istiadat dan agama pasien. Serta responden masih ada menjawab kadang kadang untuk pertanyaan memahami pasien secara terbuka dan jujur $(6,6 \%)$, memberikan pendidikan kesehatan (10\%), Menciptkan lingkungan yang kondusif dan nyaman serta memenuhi kebutuhan dasar $(3,3 \%)$.

\section{Analisis Bivariat}

Hasil analisis bivariat dilakukan untuk mengetahui hubungan karakteristik individu dan perilaku caring dengan kepuasan pasien rawat inap di RSUD Abdul Manap Kota Jambi. Adapun hasil tersebut dipaparkan seperti tabel berikut ini.

\footnotetext{
Hubungan Karakteristik dengan Kepuasan Pasien di RSUD Abdul Manap Kota Jambi Tahun 2019
} 
Ernawati dan Bettywati E Tumanggor, Hubungan Karakteristik individu dan Perilaku Caring Perawat Dengan Kepuasan pasien di Ruang Rawat Inap RSUD Abdul Manap Jambi Tahun 2019

Tabel 2. Hubungan Karakteristik individu dengan Kepuasan Pasien di RSUD Abdul Manap Kota Jambi Tahun 2019

\begin{tabular}{|c|c|c|c|c|c|c|c|}
\hline \multirow{3}{*}{ No } & \multirow{3}{*}{ Variabel } & \multicolumn{4}{|c|}{ Kepuasan Pasien } & \multirow{3}{*}{ OR } & \multirow{3}{*}{ P-Value } \\
\hline & & \multicolumn{2}{|c|}{ Puas } & \multicolumn{2}{|c|}{ Tidak puas } & & \\
\hline & & $\mathrm{f}$ & $\%$ & $\mathrm{f}$ & $\%$ & & \\
\hline \multirow[t]{3}{*}{1} & Jenis kelamin & & & & & & \\
\hline & Laki-laki & 23 & 67,6 & 11 & 32,4 & 0,770 & 0,865 \\
\hline & Perempuan & 19 & 73,1 & 7 & 26,9 & & \\
\hline \multirow[t]{4}{*}{2} & Usia & & & & & & \\
\hline & Remaja Akhir & 3 & 37,5 & 5 & 62,5 & & 0,62 \\
\hline & Dewasa & 15 & 83,3 & 3 & 16,7 & & \\
\hline & Lansia & 24 & 70,6 & 10 & 29,4 & & \\
\hline \multirow[t]{4}{*}{3} & Pendidikan & & & & & & \\
\hline & Pendidikan dasar & 17 & 63,0 & 10 & 37,0 & & 0,439 \\
\hline & Pendidikan menengah & 19 & 79,2 & 5 & 20,8 & & \\
\hline & Pendidikan tinggi & 6 & 66,7 & 3 & 33,3 & & \\
\hline \multirow[t]{3}{*}{4} & Pekerjaan & & & & & & \\
\hline & Bekerja & 26 & 70,3 & 11 & 29,7 & 1,034 & 0,964 \\
\hline & Tidak bekerja & 16 & 769 & 7 & 30,4 & & \\
\hline
\end{tabular}

Berdasarkan tabel diatas hasil analisis menunjukan responden yang berjenis kelamin laki-laki yang puas terhadap pelayanan yang diberikan perawat 23 $(67,6 \%)$, lebih tinggi dibandingkan yang tidak puas 11 $(32,4)$. Proporsi ini secara statistik tidak bermakna terlihat dari nilai $\mathrm{p}=0,865(\mathrm{p} \leq 0,05)$. Dapat disimpulkan Jenis kelamin tidak berhubungan dengan tingkat kepuasan pasien.

Hasil analisis berdasarkan umur menunjukan responden yang berusia 17-45 tahun yang puas terhadap pelayanan yang diberikan perawat sebanyak $18(69,2 \%)$, lebih tinggi dibandingkan yang tidak puas $8(30,8)$. Proporsi ini secara statistik tidak bermakna terlihat dari nilai $\mathrm{p}=1,000(\mathrm{p} \leq 0,05)$. Dapat disimpulkan umur tidak berhubungan dengan tingkat kepuasan pasien. Selanjutnya hasil analisis berdasarkan pendidikan menunjukan responden yang berpendidikan rendah yang puas terhadap pelayanan yang diberikan perawat 36 (72 $\%$ ), lebih tinggi dibandingkan yang tidak puas 14 (28\%). Proporsi ini secara statistik tidak bermakna terlihat dari nilai $\mathrm{p}=0,705(\mathrm{p} \leq 0,05)$. Dapat disimpulkan pendidikan tidak berhubungan dengan tingkat kepuasan pasien, dan untuk hasil analisis berdasarkan pekerjaan menunjukan responden yang bekerja yang puas terhadap pelayanan yang diberikan perawat sebanyak $26(70.3 \%)$, lebih tinggi dibandingkan yang tidak puas $11(29,7 \%)$. Proporsi ini secara statistik tidak bermakna terlihat dari nilai $\mathrm{p}=1,000(\mathrm{p} \leq 0,05)$. Dapat disimpulkan pekerjaan tidak berhubungan dengan tingkat kepuasan pasien

\section{Hubungan Perilaku Caring Perawat dengan Kepuasan Pasien di RSUD Abdul Manap Kota Jambi Tahun 2019}

Tabel 3. Hubungan Perilaku Caring Perawat dengan Kepuasan Pasien di RSUD Abdul Manap Kota Jambi Tahun 2019

\begin{tabular}{|c|c|c|c|c|c|c|c|c|c|}
\hline \multirow{3}{*}{ No } & \multirow{3}{*}{ Pendidikan } & \multicolumn{4}{|c|}{ Kepuasan Pasien } & \multicolumn{2}{|c|}{ Jumlah } & \multirow{3}{*}{ OR } & \multirow{3}{*}{ P- Value } \\
\hline & & \multicolumn{2}{|c|}{ Puas } & \multicolumn{2}{|c|}{ Tidak puas } & \multirow{2}{*}{ f } & \multirow{2}{*}{$\%$} & & \\
\hline & & $\mathrm{f}$ & $\%$ & $f$ & $\%$ & & & & \\
\hline 1 & Baik & 35 & 79,5 & 9 & 20,5 & 44 & 100 & 5,000 & 0,018 \\
\hline \multirow[t]{2}{*}{2} & Kurang & 7 & 43,8 & 9 & 56,3 & 16 & 100 & & \\
\hline & Total & 42 & 70,0 & 18 & 30,0 & 60 & 100 & & \\
\hline
\end{tabular}

Berdasarkan hasil analisis menunjukan responden yang perilaku caring baik yang puas terhadap pelayanan yang diberikan perawat adalah 35(79.3\%), lebih tinggi dibandingkan yang tidak puas $9(20,5 \%)$. Proporsi ini secara statistik bermakna terlihat dari nilai $\mathrm{p}=0,018(\mathrm{p} \leq$ 0,05). Dapat disimpulkan perilaku caring berhubungan dengan tingkat kepuasan pasien di ruang rawat inap RSUD Abdul Manap Kota Jambi. Dan nilai OR 5,000 artinya semakin baik perilaku caring perawat dalam memberikan asuhan keperawatan pasien 5 kali lebih puas terhadap pelayanan yang diberikan perawat.

Berdasarkan hasil analisis menggunakan chisquare menunjukkan adanya hubungan perilaku caring perawat dengan kepuasan pasien $(\mathrm{p}=0,018, \mathrm{r}=5,000)$ hubungan antara kedua variabel tersebut memiliki kekuatan yang sedang. Koefisien korelasi bernilai positif artinya semakin baik perilaku caring perawat maka pasien semakin puas. Penelitian ini dapat dilihat bahwa perilaku caring perawat mempunyai hubungan dengan tingkat kepuasan pasien diruang rawat inap RSUD Abdul Manap Kota Jambi Pernyataan ini didukung teori yang dikemukakan oleh Potter dkk., (2013) bahwa sikap perawat yang berhubungan dengan caring adalah kehadiran, sentuhan kasih sayang dan selalu mendengarkan klien. Sentuhan caring suatu bentuk komunikasi non verbal yang dapat mempengaruhi 
kenyamanan klien, meningkatkan harga diri klien, memperbaiki orientasi tentang kenyataan (Watson, 1994) dalam Potter dkk.,(2013). Berdasarkan hasil wawancara dengan responden ditemukan bahwa pasien merasa puas dengan perawat yang ramah, mudah senyum, sopan dan memberi perhatian.

Pernyataan responden tersebut sesuai dengan teori yang mengatakan bahwa caring merupakan praktik keperawatan dimana perawat membantu klien pulih dari sakitnya. Kehadiran, kontak mata, bahasa tubuh, nada suara, sikap mau mendengarkan serta memiliki sikap positif dan bersemangat yang dilakukan perawat kepada klien akan membentuk suasana keterbukaan dan saling mengerti, serta perlakuan yang ramah dan cekatan ketika melaksanakan prosedur keperawatan akan memberikan rasa aman pada klien (Potter., 2013).

Teori lain mengatakan bahwa perawatan yang efektif hanya mungkin dilakukan oleh seorang perawat yang menaru minat terhadap orang lain, tanpa menghiraukan umur, jenis kelamin, latar belakang dan status sosial ekonomi (Singgih dkk, 2012).

Menurut Morrison., (2008) bahwa keperawatan dan caring adalah sesuatu yang tidak terpisahkan dan pada saat yang sama mengindikasikan bahwa beberapa aktivitas praktik dilakukan dalam proses caring di lingkungan keperawatan.

Hasil penelitian menunjukkan bahwa ada hubungan yang signifikan antara perilaku caring perawat dengan tingkat kepuasan pasien, namun masih terdapat $20,5 \%$ yang kurang puas dengan perilaku caring perawat. Hal ini dapat disebabkan oleh pengalaman dan faktor demografi responden dalam menerima pelayanan perawat. Pernyataan ini didukung teori yang dikemukakan oleh Singgih., (2012) bahwa seorang pasien yang pada masa sehat terbiasa hidup dengan pelayanan yang sepenuhnya dipusatkan pada pemuasan semua keinginan, tentu sewaktu mendapat perawatan akan menuntut perlakuan yang sesuai dengan yang diperolehnya dalam hidup sehari-hari.

Hasil penelitian ini terdapat $43,8 \%$ yang mempunyai persepsi kurang baik tentang perilaku caring perawat (kurang caring) namun merasa puas. Hal ini dapat disebabkan oleh cara perawat dalam hubungannya dengan pesien/ keluarga. Pernyataan ini didukung teori bahwa perawat yang dapat meyakinkan pasien/keluarga akan memperoleh kepercayaan dari pasien, sehingga secara tidak langsung dapat membantu membentuk sikap positif pasien terhadap perawat. Ada orang sakit yang ingin selalu diperhatikan dan menarik perhatian perawat, ada pula pasien yang sungkan dan segan untuk memanggil dan meminta bantuan perawat (Singgih dkk.,2012).

Dari beberapa teori dan hasil penelitian tentang perilaku caring perawat dengan kepuasan pasien sangat erat hubungannya karena perlakuan perawat sebagai provider dimana pelayanan perawat harus dapat dirasakan dan memberi dampak yang positif terhadap pasien sebagai customer (pelanggan) pelayanan keperawatan di rumah sakit (Sitorus R 2013). Kepuasan pasien adalah keluaran (outcome) layanan kesehatan. Dengan demikian, kepuasan pasien merupakan salah satu tujuan dari peningkatan layanan kesehatan.

Hasil penelitian ini sejalan dengan penelitian yang dilakukan oleh (Abdullah, Saleh, \&Sjattar, 2013, ikafah 2015) yang meneliti tentang hubungan perilaku caring perawat dengan tingkat kepuasan pasien rawat inap rumah sakit menemukan ada hubungan yang signifikan antara perilaku caring perawat dengan tingkat kepuasan pasien rawat inap rumah sakit $(\mathrm{p}<0,000)$. ). Kepuasan adalah perasaan senang atau kecewa yang muncul setelah membandingkan antara persepsi terhadap kinerja atau hasil suatu produk atau jasa dan harapan-harapan (Kotler, 2007). Hal ini dipengaruhi oleh pelayanan yang diberikan, juga ditentukan oleh pengalaman dan pemikiran perorangan, dan hal ini tidak dapat dengan mudah diupayakan untuk diubah, dan digiring kearah keadaan yang memuaskan (Sabarguna, 2008). Rasa ini adalah perasaan senang seseorang yang berasal dari perbandingan antara kesenangan yang telah memenuhi harapan (Gerson, 2004) terhadap aktivitas dan suatu produk dengan harapannya (Nursalam, 2011).

Penelitian juga sejalan dengan penelitian Ahmad Rifai bahwa ada hubungan perilaku caring perawat dengan tingkat kepuasan pasien di ruang rawat ina RSUD dr Loemanohadi Kudus tahun 2018, p value 0,00 $(\mathrm{p}<0,05)$ dan hasil penelitian Umi Kalsum diruang perawatan teratai RSUP Fatmawati dengan nilai $\mathrm{p}$ value 0,001 . Suatu pelayanan kesehatan disebut sebagai pelayanan kesehatan yang bermutu apabila penerapan semua persyaratan pelayanan kesehatan dapat memuaskan pasien, didalamnya mencakup penilaian terhadap kepuasan kesehatan, kesinambungan pelayanan kesehatan, keterjangkauan pelayanan kesehatan, efisiensi pelayanan kesehatan dan mutu pelayanan kesehatan.

Hasil penelitian menunjukan hubungan yang sangat erat antara perilaku caring dan kepuasan pasien untuk itu diharapkan perawat menanamkan perilaku caring dalam memberikan asuhan keperawatan melalui komunikasi, intervensi keperawatan dan membuat penyegaran melalui pelatihan tentang caring dan penerapan dalam pelayanan keperawatan.

\section{SIMPULAN}

Berdasarkan hasil penelitian Hubungan Karakteristik individu dengan perilaku caring perawat dengan tingkat kepuasan pasien rawat inap di RSUD Abdul Manap Kota Jambi maka dapat disimpulkan sebagai berikut :Gambaran Karakateristik individu: sebagian besar jenisi kelamin laki-laki 56,7\% umur sebagian besar berusia diatas 46 tahun $56,7 \%$, pekerjaan sebagian besar bekerja $61,7 \%$ dan tingkat pendidikan sebagian besar pendidikan rendah 83,3\% , Gambaran perilaku caring perawat sebagian besar $73,3 \%$ pasien 
Ernawati dan Bettywati E Tumanggor, Hubungan Karakteristik individu dan Perilaku Caring Perawat Dengan Kepuasan pasien di Ruang Rawat Inap RSUD Abdul Manap Jambi Tahun 2019

mempersepsikan perilaku caring perawat baik. Gambaran tingkat kepusanan pasien rawat inap 70\% puas terhadap pelayanan yang diberikan perawat. Tidak ada hubungan karakteristik individu dengan kepuasan pasien rawat inap di RSUD Abdul Manap Kota Jambi, Ada Hubungan perilaku caring Perawat dengan kepuasan pasien rawat inap di RSUD Abdul Manap Kota Jambi ( $p$ value 0,018$)$

\section{DAFTAR PUSTAKA}

Abdul, Saleh, A, \& Sjattar, EL. 2013. Relationship of caring behaviors of nurses patient satisfaction level in inpatient at hospital. Makasar: Universitas Hasanuddin.

As'ad, 2011. Seri Ilmu Sumber Daya Manusia: Psikologi Industri. Edisi IV. Yogyakarta: Liberty.

Baros, Wan Aisyah, 2011, Kontribusi Pengetahuan Peserta Askes Sosial Terhadap Kepuasan Layanan Rawat Jalan Tingkat Lanjut dan Rawat Inap PT Askes Tahun 2011, Universitas Indonesia, Jakarta.

Gerson, Richard. F. 2002. Mengukur Kepuasan Pelanggan. Jakarta: Penerbit PPM

Ikafah dan Harniah. 2017. Perlaku Caring Perawat dengan Kepuasan Pasien di ruang Rawat Inap Private Care Center RSUP Wahidin Sudirohusodo. Makassar.

Kotler, Philip dan Keller, 2007, Manajemen Pemasaran, Jilid I, Edisi Kedua belas, PT. Indeks, Jakarta.

Morrison \&Burnard, 2009. Caring \& Communication. Jakarta. EGC

Nursalam. 2002. Manajemen Keperawatan: Aplikasi dalam Praktik Keperawatan Profesional. Jakarta: Salemba Medika.

Parasuraman, A. Zeithalin, VA \& Berry, L.L. 1999. A Conceptual Model Service Quality And It's Implication For Future Reseach. Journal Of Marketing, Volume 42, ISSN 1673-3864 p. 41-50.

Poter \&Perry, A.G. . 2013.. Fundamentals of Nursing : Fundamental Keperawatan (edisi 7). Terjemahan. Jakarta: Salemba Medika.

Sabarguna, BS. 2008. Manajemen Pelayanan Rumah Sakit Berbasis Sistem Informasi. Yogyakarta: Konsorsium RS Islam Jateng

Sabarguna, BS. 2008. Aplikasi Customer Relationship Management Untuk Rumah Sakit. Jakarta: Sagung Seto

Sugiyono.2012. Metode Penelitian. Bandung. Alfabeta

Singgih \& Yulia .2012. Psikologi Keperawatan .Jakarta .Gunung Mulia

Spiegel, A., \& Backhaut, B. (2008).Curing and caring: A review of factors affecting the quality and acceptability of health care. New York: Spectrum Publication.

Sitorus R.2013. Model Praktik Keprawatan Profesional di Rumah Sakit. Jakarta .EGC

Wijono, D, 1999. Manajemen Mutu Pelayanan Kesehatan, Airlangga University Press, Surabaya
Wiyana, Muncul. (2008). Supervisi dalam Keperawatan. Yogyakarta: Penerbit Andi 